\title{
RECUPERARE, VALORIFICARE, ARHEOLOGIE. MUZEE ÎN SPAT!II ARHEOLOGICE
}

arh. Maria - Alexandra Tase

Universitatea de Arhitectură și Urbanism „Ion Mincu”, București

mariaalexandra_t@yahoo.com

\section{Rezumat}

Schimbarea devine implicită atunci când intervine factorul timp, care poate fi declinat într-un timp fizic, matematic (atunci când ne referim la parametri exacți, precum 10 ani, o oră, două secole etc.), dar și într-unul pshihologic, simțit ca durată. Într-un timp fizic, lucrarea de arhitectură trece sau suferă în mod inevitabil degradări, distrugeri, este deductibilă metric, prin sistemul de măsuri, proporții, de vreme ce durata se referă la alte fluxuri spațiale și perceptive în baze subiective.

Spațiul cu care a lucrat acest timp explicat mai sus este unul vid, omogen, neanimat. Tema ruinei în raport cu timpul se îndreaptă spre valoarea memoriei. Fiecare memorie (amintire) subordonează o lume imaginară, compusă din evenimente, idei, valori morale, culturale, care adăugate arhitecturii, devin un rezultat al sedimentării lucrărilor materiale ale omului în oraș.

Muzeul contemporan de arheologie trebuie să înțeleagă o realitate trecută, moartă, dar care există numai prin vestigii, ca moaștele sale și pe care le reconstruiește într-un context imaginat, astfel încât, să poată reda o imagine a trecutului, în raport cu contaminările pe care contemporaneitatea le poate aduce.

Cuvinte cheie: arheologie, muzealizare, recuperare, conservare, valorificare, memorie, temporalitate 


\section{Spațiul și temporalitatea}

Introducerea în spațiul arheologic se va face frontal și pieziș, precum o făcea și Descartes, adică detașat, înțelegând subiectul printr-o privire lăturalnică a contextului. Acest mod de abordare nu ține seama numai de împrejurările timpurilor, ci de faptul că există un fel de a prezenta întrun spirit mai ocolit, mai „cu coada ochiului” (Patapievici, 2017). Spațiul arheologic este unul aparte față de spațiul contemporan, întrucât se află în strânsă legătură cu timpul. Nu putem vorbi despre arheologie, dacă nu o reperăm în timp.

Dat fiind că o clădire este supusă efectelor timpului din primele secunde ale existenței sale, ea nu poate fi considerată ca un produs finit, înghețat în timp, bătut în piatră. Prin urmare, timpul nu doar implică noțiunea de îmbătrânire, cât mai degrabă ideea de schimbare. O clădire supraviețuiește de-a lungul timpului datorită capacității sale de a fi utilizată și de a evolua, de a oferi o anumită formă de flexibilitate și adaptabilitate permanentă. (Bogdan \& Van Broeck, 2018)

Schimbarea devine implicită atunci când intervine factorul timp, care poate fi declinat într-un timp fizic, matematic (atunci când ne referim la parametri exacți, precum 10 ani, o oră, două secole etc.), dar și într-unul pshihologic, simțit ca durată. Într-un timp fizic, lucrarea de arhitectură trece sau suferă în mod inevitabil degradări, distrugeri, este deductibilă metric, prin sistemul de măsuri, proporții, de vreme ce durata se referă la alte fluxuri spațiale și perceptive în baze subiective.

Spațiul cu care a lucrat acest timp explicat mai sus este unul vid, omogen, neanimat. Tema ruinei în raport cu timpul se îndreaptă spre valoarea memoriei. Fiecare memorie (amintire) subordonează o lume imaginară, compusă din evenimente, idei, valori morale, culturale, care adăugate arhitecturii, devin un rezultat al sedimentării lucrărilor materiale ale omului în oraș.

Muzeul contemporan de arheologie trebuie să înțeleagă o realitate trecută, moartă, dar care există numai prin vestigii, ca moaștele sale și pe care le reconstruiește într-un context imaginat, astfel încât, să poată reda o imagine a trecutului, în raport cu contaminările pe care contemporaneitatea le poate aduce.

Odată cu trecerea timpului fizic, diferitele elemente decorative dispar, obiectul își pierde fragmentele, iar ceea ce rămâne devine nucleul său esențial, singurul element evident, transformarea în esență spațială (Fabbrizzi, 2015). Imaginea ruinei, fragmentele pe care le mai vedem azi sunt clasicizarea stilistică a arhitecturii antice. Procesul deformării inevitabile produse de timpul fizic face ca toate ruinele să arate la fel, ca după o pierdere generală de sens și valoare arhitecturală. Numai atunci când devine ruină, arhitectura poate aspira să facă parte din natură, și numai dacă ruina a devenit natură, „și-a atins dimensiunea estetică independentă și se poate declara îndeplinită" (Fabbrizzi 2015, p. 12). Dar în multe cazuri, ruinele arheologice nu reprezintă decât resturi, un morman de moloz și doar atunci când devin parte a unei intervenții contemporane, sunt restaurate sau consolidate, reușesc să stârnească interes și restabilesc sentimentul lucrării lor inițiale. Muzeul de arheologie redefinește relațiile slabe dintre arhitectură și context, fie el fizic, social sau cultural.

Ruinele arheologice sunt martorul efemerității oricărui proiect făcut de om. Walter Benjamin a spus odată că reprezintă emblema fragilității noastre ca existență. Istoria este o realitate în mare parte străină. Conceptul de ruină aduce cu sine ideea că arta ar trebui să fie investigată într-o manieră "materialistă". Istoriografia burgheză sporește, mai presus de toate, legătura cu tradiția culturală, mizează pe recunoaștere, pe materialismul istoric, lucrează cu fragmentele într-un mod foarte vizibil și impunător. Abia în Renaștere s-a născut un interes 
pentru civilizația greacă antică, iar prin ruinele trecutului s-a putut identifica forma completă, pură a lucrărilor antice și originale. Adevărata „estetică a ruinelor" a fost dezvoltată în secolul al XVII-lea, când Denis Diderot plasează mediul arheologic antic într-un sens mai general al trecutului și spune că „ruinele sunt martori muți” (Diderot apud Orlando, 1994, pp. 108-9) percepția ca o expresie a precarității. Neoclasicismul a încercat să reinventeze aceste forme dispărute, de la Canova la Winckelmann, în timp ce din a doua jumătate a secolului al XVIII-lea se dezvoltă gustul pentru arhitectura gotică, arhitectură care în comparație cu proporțiile neoclasicului, se prezintă disproporționată și neregulară.

Mai departe, în primii ani ai secolului al XVIII-lea ruina va fi considerată importantă, ca semn și urmă ale timpului. Așa cum scria Francois-Rene de Chateaubriad în „Geniul Creștinismului”: „Toți oamenii au o admirație secretă pentru ruine” (de Chateaubriad 1996, p. 12).

\section{Abordări contemporane în spații arheologice}

Obiectul de arhitectură trebuie să rămână semnificativ pe toată durata existenței sale. Perioada postmodernă a dezvoltat o serie de obiecte muzeale de sine stătătoare, autosuficiente și fără o interdependență cu metropola. În lipsa unei identități culturale se poate ajunge ușor la un consum aleator de spațiu, care transforma peisajul într-unul greu de utilizat.

Pentru documentarea muzeelor aflate în contextul unui sit arheologic se vor analiza numai acele exemple capabile să demonstreze că în spatele formei arhitecturale se găsește caracterul emblematic, simbolismul și o anume filosofie a proiectării. Vor fi neglijate cele care implică o singură relație tautologică față de urmele trecutului sau se preocupă doar de dimensiunea fizică a relevării, cauzată de constrângerile factorilor exteriori. Există în lume nenumărate propuneri și soluții adaptate zonelor geografice, care au recurs la utilizarea unor structuri speciale, tehnologii recurente, care în majoritatea cazurilor sunt incapabile să nască valențe și relații între noile forme și vechile urme, cât și între ele și mediul care le găzduiește. Cu toate acestea, alte proiecte au mers pe calea recunoașterii datelor antropologice, au acordat un interes major artefactelor și modului în care aceste „resturi” au fost în măsură să se formeze. Sunt proiecte capabile să interpreteze într-un mod sensibil valențele proprii ale diverselor contexte arheologice cu care relaționează, care propun o soluție difuză și caută să insereze prezența arheologiei într-un raport dezirabil de continuitate cu prezentul.

Căile de muzealizare pot fi multiple, dar vor fi folosite cele potrivite limbajului ruinelor, unul minimalist, care ne permite să înțelegem mai bine puterea arheologică a preexistenței. În aceste exemple definitivarea volumetrică a noii propuneri, precum și expresia ei vor fi modeste și riguroase. Există și arhitecturi care se încadrează în registrul de expresie, care îl depășește pe cel al metaforii, cu scopul de a da o mai mare importanță unicității ruinelor. Când acești parametri sunt prea puternici, cum se întâmplă adesea în cazul muzeului contemporan, arhitectura devine autoreferențială și ajunge să iș̦i răspundă doar sieși sau elementelor sale de definire lingvistică și spațială. Cu alte cuvinte, asistăm la o propunere de valorizare și protejare, în care forța învelitorii o depășește cu mult pe cea a conținutului.

În multe cazuri valorizarea arheologiei devine motivul unui proiect în care se încearcă forțarea limitelor obișnuite ale dimensiunii fizice sitului arheologic, pentru a naște un reper de la distanță. Folosirea intensă a cortenului, a oțelului, a căror imagine oxidată devine o metaforă a timpului asupra materiei, duritatea și lipsa omogenității din tonalitatea acestor materiale, precum și imperfecțiunea lor este compensată de aceeași imperfecțiune a ruinelor. Putem spune că folosirea cortenului reprezintă cea mai vizibilă alăturare a arhitecturii contemporane 
de peisajul arheologic. Un soi de „brand” al vremurilor, care a reușit să devină emblematic pentru epoca noastră în materie de muzealizare, și-a atins nivelul de clasicizare stilistică.

O altă expresie posibilă este cea care ține de topografie. Peisajul și arhitectura nu mai reprezintă două cadre separate, ci formează o nouă categorie care le conține pe ambele, le unifică într-o formă inedită de comuniune totală, bazată pe relaționarea reciprocă. Nu putem nega și categoria intervențiilor care nu își depășesc dimensiunea tehnologică, dar care prin simpla formă tectonică îndeplinesc valoarea de protejare.

Ruina este vocea care compune în totalitate locul, iar până la urmă, arhitectura nouă va fi construită pentru a o scoate în evidență și pentru a-i descoperi sensurile deja prezente în context. Siturile arheologice aflate în centrul unui oraș sau la marginea orașului, scoase de cele mai multe ori din context, ar putea regenera orașul printr-o integrare corectă. Un sit arheologic poate fi descoperit prin săpături și lăsat la vedere, fără să existe alte tehnici speciale cu rol de adăpostire sau conservare sau poate fi inserat într-un muzeu, care să devină un centru de interes. Deci, referirea nu trebuie să se rezume doar la o intervenție de tehnică arhitecturală (cum se clădește un muzeu pe o ruină), ci și la una urbană, la modul în care un obiect antic poate fi (re)descoperit, revelat prin simpla „scoatere la suprafață”.

Imaginea arhitecturii de astăzi este în general ușor recognoscibilă, mai ales dacă se află sub semnătura unui arhitect. Dar atunci când vine vorba despre situri arheologice, limbajul trebuie să se schimbe, să contureze un instrument cognitiv modest și să nu epateze, să fie cuminte și să se supună monumentalității trecutului. Putem pune în balanță două metode de abordare în vederea "alegerii" tipului de arhitectură folosit în mediul arheologic: una de calități strict formale, care devin intruzive pentru locul pe care îl ocupă în oraș versus o intervenție de „resturi ruginite” ${ }^{1}$, dar care lucrează în slujba dominației preexistentului, fără a avea un caracter de subordonare a arheologiei și fără a se distinge ca barieră vizuală între istorii.

Arheologia se va dezvolta ca parte a cercetării urbane și ca o metodologie a unei construcții narative. Memoria socială se constituie din elemente, semne reprezentative unei singure comunități, chiar circumstanțe, fără a forma un patrimoniu comun. Funcție de tipul de memorie se pot identifica două categorii de spații: congestionat (subiect de politică culturală) și abandonat (de tip urban, care să nu aparțină percepției colective); lipsa relației cu contextul face situl, în general, inaccesibil.

Arheologia poate fi muzealizată atunci când i se atribuie valoare de memorie. Kazmer Kovacz subliniază memoria în concepția arhitecturală, spunând că orice obiect are „o dublă deschidere [...] dată în timp: către un trecut și către un viitor" (Kovacz 2013, p. 18). Și demonstrează că „valoarea unui ansamblu patrimonial poate crește prin reintegrarea unei arhitecturi noi, care cinstește în același timp lucrul și memoria vechilor constructori [...] practicile memoriale de astăzi sunt împietrite într-un respect paralizant și la urma urmei, neconstructiv." (Kovacz 2003, pp. 106-110).

Valoarea istorică a patrimoniului este mare, dar acest lucru devine apăsător, încât cu greu ne mai permitem să lucrăm cu el, deoarece patrimoniul capătă de multe ori un caracter intangibil. Ca moștenitori vrem să găsim, totuși, o cale prin care să îi permitem să își continue viața, să evolueze plastic, pentru a se adapta noilor funcțiuni pe care vrem să le îndeplinească, ceea ce implică implementarea de noi tehnologii.

\footnotetext{
${ }^{1}$ așa cum a numit Vittorio Sgarbi materialele intens folosite în arheologie, precum cortenul n.r. "ferraglia arrugginita"
} 
Oare atitudinea de protejare exagerată nu provine dintr-o interpretare greșită a termenului? Francois Seigneur insistă pe definiția patrimoniului în sensul că nu reprezintă un obiect pietrificat, destinat numai admirației, ci evocă un proces transmisibil, perpetuabil și, deci, modificabil (Zuber, 1972, p. 13). Avem nevoie de mai mult curaj în abordarea trecutului pentru a adăuga și alte straturi de semnificație moștenirilor noastre. În cazul acestor abordări, antagonismul nu este între memorie și uitare, cât între memorie, creație și autenticitate.

Încă este greu de lămurit care ar putea fi relația corectă la nivel obiectiv între ruină, ca mărturie a istoriei și obiectul de arhitectură inserat în contextul său.

\section{Domenii de analiză ale unui sit relevat}

Pentru a deveni un element de „interes muzeal”, situl arheologic descoperit va fi analizat din perspectiva celor trei domenii: restaurativ, compozitiv și tehnic (Caliari, 2012). Prin acestea, procesul de muzealizare vrea să fie recognoscibil ca abordare, expresivitate, pentru a se putea citi mai usor caracterul de autenticitate. S-au formulat opinii și s-au făcut paralele la situația siturilor arheologice descoperite în ultimii ani, iar Sandro Ranellucci a încercat să definească aceste referințe ca „paralelisme pe mai multe benzi” (Ranelucci, 2012, p. 13).

Ceea ce se poate defini, în termeni științifici, ca fiind „domeniul restaurării” (Ranelucci, 2012), este acela care crează o imagine omogenă și compactă. Studiile de caz referitoare la domeniul restaurativ arată clar că sunt legate de nevoile autentice și de recuperarea de sensuri. Restaurarea arheologică este o lectură interpretativă a existentului și a ceea ce a rămas ca mărturie a trecutului.

Destul de diferită de cea a restaurării, a doua abordare care aduce arhitectura într-un sit arheologic, coroborează starea de memorie și a fost definită ca „domeniu compozitiv" (Ranelucci, 2012). Această analiză tinde să îmbunătățească învelișul și, implicit, calitatea generală estetică a sitului.

Mergând pe o cale ceva mai rigidă, cu mai multe constrângeri, dar cu o abordare mult mai practică și inginerească, în lucrul cu situl arheologic se poate aplica „domeniul tehnic” (Ranelucci, 2012). Această metodă este favorabilă de cele mai multe ori, pentru că oferă garanția unor soluții rapide în execuție, mai avantajoase din punct de vedere economic. Atunci când conservarea siturilor arheologice se bazează în principal pe caracterul tehnologic, se folosesc sisteme predominant ușoare și reversibile ca montare, copertine mai mult sau mai puțin complexe. Aceste structuri sunt modulare, lejere, adoptate pentru a proteja "documentele" arheologice, pentru a le integra sau pentru a le completa. Când vine vorba despre punerea în operă, calea tehnologică este adesea adoptată, întrucât oferă multe soluții de muzealizare in situ, care aprofundează problematica sistemelor protective în caz de urgență, aflate la limita între a fi numai provizorii sau a îmbrăca un caracter definitiv. Acest studiu are ca scop menținerea unui conținut coerent și unitar, precum și relația strânsă dintre elementele descoperite și artefactul proiectat, limitat, de cele mai multe ori, de singura sa funcționalitate protectivă. Predomină în acest tip de abordare structurile metalice din oțel, oțel vopsit sau aluminiu; asamblate, sudate sau prinse în bolțuri; cu suprafața de protecție amplasată orizontal, sau în formă curbă, PVC, plexiglas sau din metal pliat ${ }^{2}$. La fel cum s-a verificat și în exemplul deja emblematic al acoperirii lui Franco Minissi din Piazza Armerina,

\footnotetext{
2 Evident, există și alte soluții derivate din nevoile specifice, în special cele de protecție la ploaie, dar acestea nu sunt luate neapărat în discuție, deaorece au un scop exclusiv de bază și nu reprezintă un model estetic pentru proiectul de muzealizare, la care acest text face referire.
} 
Sicilia; unde esențialitatea structurii constructive și a calității materialelor este suficientă pentru că include acest tip de sisteme de protecție din categoria tehnologiilor ușoare, reversibile, temporare. Și astfel rezultă o funcțiune deconstruită, indusă de soluție, mai degrabă.

Alăturarea dintre vechi și nou are o dimensiune „cosmetică” atunci când vine vorba despre integrarea contemporanului în mediul istoric. Relația nou-vechi face ca „vechiul” să devină „nou"; avem, de fapt, o nouă interpretare a „vechiului”, ceea ce face ca abordarea să devină cu mult mai relativă și conduce arhitectura spre o gamă largă de intervenții posibile. Probabil că pentru relația „"nou-vechi” trebuie a se găsi o nouă terminologie, iar spațiile - construite cu mai multă flexibilitate în structură și arhitectură.

\section{Recuperarea și valorificarea - un pas înainte}

Limbajul estetic al unui astfel de proiect trebuie să rămână departe de standardizare, clișee sau anonimat și mai aproape de context, discreție și personalizare prin integrare. Un sit arheologic va fi o continuă sursă de informații și foarte rar săpăturile se încheie definitiv. Un muzeu pe un sit arheologic devine astfel un spațiu destinat studiului continuu, care poate să schimbe percepția asupra unei ruine. Deci, mesajul principal al său nu este producerea de spații, ci comunicarea și capacitatea narativă. Realitatea ne-a demonstrat că tradiția (care nu face decât să conserve, fără a merge mai departe, la scară urbană) nu este aproape de nevoia actuală a monumentului, de a-și reinventa funcțiunea.

Pentru a menține o ruină în viață, timpul și schimbarea devin parametri esențiali. Conservarea și valorificarea vor merge mai departe de înghețarea sterilă a unei moșteniri retrograde. Chiar din contră, o nouă intervenție se va supune unei permanente transformări în utilizare, deoarece arhitectura contemporană se află în relație directă cu reînnoirea socială, economică și culturală. În ceea ce privește patrimoniul arheologic, restaurarea, conservarea și valorificarea sa devin proiecte de „reciclare” și durabilitate culturală. Prin urmare, cea mai bună formă de păstrare devine re-utilizarea. Proiectul de arhitectură care servește unui astfel de demers nu va genera "spații” și "clădiri fixe”, ci mai curând proiecte aflate în evoluție și adaptare la interacțiunea cu orașul. Un astfel de răspuns poate clasa propunerea într-un rol social, care va da un alt sens patrimoniului.

Conservarea începe cu existentul, iar acest lucru înseamnă o abilitate pentru a face ca noul proiect să se integreze în loc. Prin definiție, proiectul de conservare/restaurare/valorificare este un omagiu adus culturii și mentalității străvechi, căreia arhitectul îi poate adăuga o nouă dimensiune, o nouă funcțiune, o nouă frumusețe, un nou recurs.

\section{Referințe}

Bogdan \& Van Broeck, (martie-mai 2018) Nu (re)construi dacă nu trebuie. BOGDAN \& VAN BROECK: COOP - Reconversia unei mori vechi, Zeppelin, 149, Articol preluat din https://e-zeppelin.ro/nureconstrui-daca-nu-trebuie-bogdan-van-broeck-coop-reconversia-unei-mori-vechi/

Caliari P-F. (2012), Premio Piranesi, Prix de Rome, Conferință internațională, Roma

de Chateaubriad, (1996), Genie du Christianisme, Paris: Flammarion

Fabbrizzi F. (2015), Con Le Rovine, Edifir, Firenze

Kovacz K. (2013), Arhitectura în continuitate, București: Paideia 
Kovacz K.(2003), Timpul monumentului istoric, București, Paideia

Orlando F. (1994), Gli oggetti desueti nelle immagini della lietteratura. Rovine, reliqueie, rarita, robaccia, luoghi inabitati e tesori nascosti, Torino: Einaudi

Patapievici H-R. (2017), conferință Spațiul public în timp, UAUIM

Ranelucci S. (2012), Conservazzione e musealizzazione nei siti archeologici, Milano: Gangemi Editore

Zuber Ch. (1972), Laissez les vivre!, Paris: Presses de la cité 


\section{RECOVERY, CAPITALISATION, ARCHEOLOGY. MUSEUM IN ARCHEOLOGICAL SITES}

arch. Maria - Alexandra Tase

University of Architecture and Urbanism „Ion Mincu”, Bucharest

Mariaalexandra_t@yahoo.com

\section{Abstract}

The change becomes inevitable when it comes to the time factor, which can be expressed in a physical, mathematical time (when we talk about precise parameters, such as ten years, one hour, two centuries, etc.), but also in a psychological one, as a duration. In a physical time, the architectural work undergoes through degradation, destruction, becomes metrically deductible, via the system of measures, proportions, since the duration refers to other spatial and perceptual flows regarding subjective bases.

The space with which the time mentioned above worked is an empty, homogeneous, unanimated one. The relationship between the theme of ruin and time goes towards the value of memory. Each memory subordinates an imaginary world, consisting of events, ideas, cultural and moral values, that added to architecture become a result of the sedimentation made by humans regarding material works in the city.

The contemporary archaeological museum must understand a past and dead reality, that occurs only through artefacts, like its relics and which rebuilds them in an imagined context so that they can show a picture of the past in relation to the contamination brought by the present.

Cuvinte cheie: archeology, museum, recovery, conservation, capitalise, memory, temporality 


\section{Space and temporality}

The introduction into the archeological space will be frontal and slick, as did Descartes, meaning detached, understanding the subject through a glance of the context. This approach does not only take account of the circumstances of the times, but of the fact that there is a way of presenting in a more devious spirit, more "with the tail of the eye" (Patapievici, 2017). Archaeological space is one that is distinct from contemporary space as it is closely related to time. We can not talk about archeology unless we spot it in time.

Regarding the fact that a building becomes a subject to the effects of time starting the first seconds of its existence, it can not be defined as a finite product, frozen in time, set in concrete. Thus, time not only implies the aging concept, but rather the idea of change. A building persists over time due to its ability to be used and to evolve, to provide a specific form of flexibility and permanent adaptability. (Bogdan \& Van Broeck, 2018)

The change becomes inevitable when it comes to the time factor, which can be expressed in a physical, mathematical time (when we talk about precise parameters, such as ten years, one hour, two centuries, etc.), but also in a psychological one, as a duration. In a physical time, the architectural work undergoes through degradation, destruction, becomes metrically deductible, via the system of measures, proportions, since the duration refers to other spatial and perceptual flows regarding subjective bases.

The space with which the time mentioned above worked is an empty, homogeneous, unanimated one. The relationship between the theme of ruin and time goes towards the value of memory. Each memory subordinates an imaginary world, consisting of events, ideas, cultural and moral values, that added to architecture become a result of the sedimentation made by humans regarding material works in the city.

The contemporary archaeological museum must understand a past and dead reality, that occurs only through artefacts, like its relics and which rebuilds them in an imagined context so that they can show a picture of the past in relation to the contamination brought by the present.

Along with the passing of the physical time, comes the disappearance of different decorative elements, the object loses its parts and what remains becomes its core - the only obvious element: the transformation into a spatial essence (Fabbrizzi, 2015). The image of the ruin, the parts that we still see today, are the stylistic classification of ancient architecture. The process of inevitable deformation - produced by the physical time - makes all ruins identical, as if they lost their sense and architectural value. Only after turning into ruin, architecture can aspire to be part of the nature and only if the ruin has become nature "it has reached its aesthetic independent dimension and can be declared fulfilled" (Fabbrizzi, 2015, p. 12). But in many cases archaeological ruins are nothing more than scraps, a mound of rubble and only when they become a part of a present intervention they are restored or consolidated, they succeed in inducing sympathy and they reestablish the memory of their original work. The archaeological museums need to bring back the weak or inexistent relationship between architecture and context, whether it is physical, social or cultural.

The ephemeris of any project made by men is proved by archaeological ruins. Walter Benjamin once said that "it is the emblem of our fragility as existence". History is a largely foreign reality. The concept of ruin brings with it the idea that art should be investigated in a "materialistic" manner. Above all, bourgeois histography increases the cultural link, relies on recognition, on historical materialism and works with small parts in a very imposing and visible way. It was only 
in Renaissance that an interest for Ancient Greek civilization was born and the pure form of ancient and original works could have been identified through past ruins. The real "aesthetic of ruins" was developed in the $17^{\text {th }}$ century, when Denis Diredot defines the ancient archaeological environment in a more general sense of the past and says that "the ruins are mute witnesses" (Diderot apud Orlando, 1994, pp. 108-9) - the perception as an expression of precariousness. Neoclassicism tried to reinvent these missing forms, from Canova to Winckelmann, while in the second half of the $18^{\text {th }}$ century the taste for Gothic architecture is growing - architecture that was disproportionate and irregular in comparison to the size of neoclassicism. This "taste" for "misshapen" can be developed in favour of ruins.

Furthermore, during the first years of the $18^{\text {th }}$ century the ruin will be considered important, representing a sign and trace of time. As Francois-Rene of Chateaubriad wrote in The Genius of Christianity: "All human beings have a secret admiration for ruins" (de Chateaubriad, 1996, p. 12).

\section{Contemporary approach in archeological sites}

The object of architecture must remain significant throughout its existence. The postmodern period has developed a number of independent, self-sufficient museum objects without interdependence with the metropolis. In the absence of a cultural identity, it is easy to reach a consumer of space, transforming the landscape into a difficult one to use.

In order to analyse museums in the state version of the archeological context, we will analyze only those examples capable of demonstrating that behind the architectural form exists the emblematic character, the symbolism and a certain philosophy of design. Will be neglected the ones which involve a single tautological relationship regarding the past or examples that concern only the physical part of the project, caused by the constraints of the external factors. There is a vast number of proposals and projects adapted to geographic areas, which have applied for the use of special structures, recurrent technologies which in most of the cases are incapable to emphasize the valences and relationships between new forms and old traces, as well as between them and the environment which host them. However, other projects have advanced on the recognition of antrophic data, have attached great importance to artifacts and the way these "remains" have been able to form. These are projects capable of interpreting sensitively their own archeological valences with the various contexts of care related, care for a diffuse solution and reach to insert Archeology in the presence of the undesirable report with continous present. A Present, a Past and a Future - they are all represented by the practice of contemporary design, which in many cases, merging beyond simple conservation capacity, but rather make up the new complexity.

The musealisation projects may take multiple paths but there will be used those thar are suitable to the language of ruins, a minimalist one, that allows us to understand better the preexistence of the Archeology. In these examples, the volumetric finalization of the new proposal, as well as its expression, will be modest and rigorous. There are also architectures that fit into the expression register, which goes beyond the metaphors, in order to give more importance to the uniqueness of the ruins. When these parameters are too strong, as is often the case with the contemporary museum, architecture becomes self-referential and reaches only its linguistic and spatial elements of sales and definition. In other words, we are witnessing a proposal for capitalization and bidding, in which the overwhelming force far exceeds that of the content. 
In many cases, the value of archeology becomes the reason for a project that tries to force the usual boundaries of the physical size of the archaeological site in order to produce a distant landmark. The intense use of corten, of steel, which have an oxidate image that becomes a time metaphor as their imperfection is offset by the same imperfection of the ruins. We may say that the use of corten represents the most visible addition of present arhitecture to the archaeological landscape. A sort of "brand" of the times, which has succeeded in becoming emblematic during our age in the field of museums, has reached its level of stylistic classicization.

Another possible expression is the one related to topography. Landscape and arhitecture no longer represent two different things, but they form a new category that includes both of them, it unites them in a unprecedented shape of total communion, based on mutual relationship. We can not deny also the category of interventions that do not exceed their technological dimension, but which through the simple tectonic form fulfill the protection value.

The ruin is the voice that defines the place and after all, the new arhitecture will be buid to highlight it and to discover its already existing contexts. Archaeological sites located in the center of a city or at its periphery are often removed from the context, but they could regenerate the city through a proper integration. An archaeological site can be discovered by digging and spotting, without the existence of any special techniques to deposit and to preserve them or it can be kept into a museum, to become a center of interest. So the reference shall not be limited only by a specific intervention of arhitectural technique (how to build a museum on a ruin), but also to an urban one, to the impact suffered by an ancient object which can be rediscovered, revealed by mere "surface removal".

The present image of the arhitecture is in general easily recognizable, espacially if it is under the signature of a starhitect. But when it comes to archaeological sites, the language used must change, must shape a modest, cognitive tool and not to astound, but to obey the past monumentaly. We can balance two methods/approaches for selecting the type of arhitecture used in the archaeological environmet: one of the strictly formal qualities, which become intrusive regarding the place they ocupy in the city versus "rusty remnant" 1 intervention, but one which works in the service of preexistent domination, without having a subordinate character of archeology and without distinguising itself as a visual barrier between histories.

Archeology will develop as part of urban research and as a method of narrative construction. Social memory consists of elements, representative signs of a single community, even circumstances without forming a common heritage. It is addressed to a unique society, to a privileged class which can access that specific archeological area. Based on the type of memory allocated, we can identify two categories of spaces: congested (subject of cultural policy) and abandoned (meaning urban, not belonging to a collective perception); the lack of relationship with the context makes the site generally inaccessible.

When it is assigned as memory value, archeology can be muzealized and may become as a museum. Kazmer Kovacz underlines memory in the architectural vision, saying that each object has "a double opening [...] created in time: towards a past and a future" (Kovacz, 2013, p. 18). And it demonstrates that "the value of a patrimony ensemble can be increased be reintegrating a new architecture that honors in the same time the work and memory of the old builders [...]

\footnotetext{
${ }^{1}$ As Vittorio Sgarbi named the intense used materials, like the corten n.r. ferraglia arrugginita
} 
memory practices that exists nowadays are blocked in a paralyzing sense of respect, and after all, unconstructive" (Kovacz, 2003, p. 106-110).

The historical value of the heritage is great, as this fact becomes oppressive, so that we can hardly afford to work with it because the patrimony often acquires an intangible character. However, we - as heirs - want to find a way which allows them to continue their lives, to evolve plastically, in order for them to adapt to the new functions we want them to be fulfilled, which involves the implementation of new technologies.

What if the exaggerated protection attitude does not come from a misinterpretation of the term? Francois Seigneur insists on the definition of heritage in the sense that it is not a pietrified object designed only for admiration, but it also provokes a transmissible, perpetual and therefore, changeable process (Zuber, 1972, p. 13). We need to have more courage in dealing with the past in order to add new layers over the significance of our inheritances. When it comes to these approaches, the antagonism is not between memory and loss, but between memory, creation and authenticity. It is still difficult to establish which can be the objective relationship between the ruin as a testimony of history and the object of architecture inserted in its context.

\section{Analysis areas of a revealed site}

In order to become a "museal interest", the revealed archaeological site shall be analyzed from the perspective of three fields: restaurative, compositive and technic (Caliari, 2012). Through these areas, the musealization process will be recognizable as an approach, eloquence, in order to emphasize the authenticity character. Opinions have been formulated and made parallel to the situation of the archaeological sites discovered in recent years, so Sandro Ranellucci has attempted to define these references as „multi-lane parallelism“ (Ranelucci, 2012, p. 13).

What can be defined in scientific terms to be part of a "restaurative area" (Ranelucci 2012) is the one that creates an homogeneous and compact image. Case studies that refere to this field clearly demonstrates that they are related to the need of authenticity and meaning recovery. The archaeological restoration designing is often seen as an interpretative lecture of the existance and what is left as a testimony of the past.

Different from restoration, the second approach that brings architecture in an archaeological site, corroborates the memory and had been defined as the "compozitive area" (Ranelucci, 2012). This analyse tends to improve the exterios image and, implicit, the overall aesthetic quality of the site.

Going on a more rigid path, with many constrains, but with a practical and engineering approach, we can apply the „technical field“ (Ranelucci, 2012). This method is often favorable because it guarantees faster solutions for execution and advantageous by the economic point of view. When the conservation of archaeological sites lies mostly on the technological character, predominant light systems are used, reversible as mount, more or less complex awnings. These structures are modular, lightwight, adopted to protect archaeological documents, to integrate or complete them. When it comes to execution, the technological field may be easily adopted, as it can offer many solutions of musealization in situ, which deepens the issue of emergency protection systems at the limit of being only temporary or definitive. This study aims to maintain an unitary content, as well as the close relationship between the discovered elements and the designed artefact, often confined to its protective 
function. Metal-steel structures, painted steel or aluminium predominate in this type of approach, assembled, welded or bolted, with horizontal or curved surface of PVC, plexiglass or folded metal. ${ }^{2}$ As the emblematic example of "minissian” cover of Piazza Armerina, where the essence of constructive structure and material quality is sufficient because includes such protection systems as light, reversible, temporary technologies. And so it results a deconstructed function, induced by the solution.

Putting together the new and old mostly has a cosmetic dimention when it comes to contemporary integration in the historic field. The new-old relation makes the "old" become "new" and here we have, in fact, a new interpretation of the "old“, which makes the approach much more relative and leads architecture to a wide range of possible interventions. Probably new terminology needs to be found, and build spaces with more flexibility in structure and architecture.

\section{Recovery - as a step forward}

The aesthetic language of such a project needs to remain far from standardization, clichee or anonymity and closer to context, discretion and personalization through integration. An archaeological site will be a continuous sourse of information and rarely digging ends definitively, because there are always immediate neighborhoods that want to be revealed and want to enrich the scientific environment. A museum built on an archaeological site thus become a space for continuous study, which can change the perception of a ruin. So, its message is not space production, but communication and narative capacity. Reality has shown us that the tradition (that only preserves without going further on an urban scale) is not close to the actual need of the monument, that of reinventing its function.

In order to maintain a ruin alive, time and change become essential parameters. Preservation and capitalization will go further than the sterile freeze of a retrograde heritage. On the contrary, a new intervention will undergo a permanent transformatio in use, because contemporary architecture has a direct relation with social, economic and cultural renewal. When it comes to archaeological heritage, restoration, preservation and valorisation tend to be projects of "recycling” and cultural sustenability. Therefore, the best form of preserving is re-using. The architectural project that serves such an approach will not generate spaces and fixed buildings, but rather evolving projects adapted to the interaction with the city. Such a response can classify the proposal in a social role, which give another meaning to the heritage.

Preserving begins with the existing and this is an ability to make the new project integrate into the city. By definition, the preservation/restoration/valorization project is a tribute to ancient culture and mentality, to whick the architect can add a new dimention, a new function, a new beauty, a new appeal.

\section{References}

Bogdan \& Van Broeck, (martie-mai 2018) Nu (re)construi dacă nu trebuie. BOGDAN \& VAN BROECK: COOP - Reconversia unei mori vechi, Zeppelin, 149, Articol preluat din https://e-zeppelin.ro/nureconstrui-daca-nu-trebuie-bogdan-van-broeck-coop-reconversia-unei-mori-vechi/

\footnotetext{
2 Obviously, there are other solutions derived from specific needs, especially rain protection, but they are not necessarily under discussion because they have an exclusively basic purpose and are not an aesthetic model for the museum project, to which this text referred to
} 
de Chateaubriad, (1996), Genie du Christianisme, Paris: Flammarion

Fabbrizzi F. (2015), Con Le Rovine, Edifir, Firenze

Kovacz K. (2013), Arhitectura în continuitate, București: Paideia

Kovacz K.(2003), Timpul monumentului istoric, București, Paideia

Orlando F. (1994), Gli oggetti desueti nelle immagini della lietteratura. Rovine, reliqueie, rarita, robaccia, luoghi inabitati e tesori nascosti, Torino: Einaudi

Patapievici H-R. (2017), Spațiul public în timp conference, UAUIM

Ranelucci S. (2012), Conservazzione e musealizzazione nei siti archeologici, Milano: Gangemi Editore

Zuber Ch. (1972), Laissez les vivre!, Paris: Presses de la cité 